\title{
CHARACTERIZATION AND CYTOTOXIC PROPERTY OF A LADDER-LIKE POLYMERIC SILVER(I) COMPLEX DERIVED FROM 3-AMINOPYRAZINE-2-CARBOXYLIC ACID
}

\author{
G.-S. Li, H.-L. Zhang \\ Key Laboratory of Surface \& Interface Science of Henan, School of Material \& Chemical Engineering, Zhengzhou \\ University of Light Industry, Zhengzhou 450002, P. R. China \\ E-mail: gangsen_li@126.com
}

Received June, 16, 2014

\begin{abstract}
A novel ladder-like polymeric silver(I) complex, $\left[\mathrm{Ag}_{2} \mathrm{~L}_{2}\right]_{n} \cdot 2 n \mathrm{H}_{2} \mathrm{O}$, where $\mathrm{L}$ is 3 -aminopyrazine-2-carboxylate, was obtained by the reaction of 3-aminopyrazine-2-carboxylic acid and silver oxide in aqueous ammonia. The complex was characterized by elemental analysis, IR spectra and single crystal X-ray determination. The smallest repeat unit contains a $\left[\mathrm{Ag}_{2} \mathrm{~L}_{2}\right]$ moiety and two water molecules. The Ag $\cdots$ Ag distance is 3.176(1) mmol. Each Ag atom is in a $\mathrm{Y}$-shaped coordination, with one carboxylate $\mathrm{O}$ and two pyrazine $\mathrm{N}$ atoms from two ligands. In the crystal structure of the complex, the dinuclear silver moieties are linked through 3 -aminopyrazine-2-carboxylate ligands, to form 1D ladder-like chain along the $b$ axis. The water molecules are linked to the silver chain through hydrogen bonds. There are $\pi \cdots \pi$ interactions between the chains. The complex showed effective cytotoxic property on human lung cancer cell line A549.
\end{abstract}

DOI: $10.15372 / J S C 20150824$

Ke yw or d s: silver complex, polymeric complex, 3-aminopyrazine-2-carboxylate, crystal structure, cytotoxicity.

\section{INTRODUCTION}

Silver complexes with carboxylate ligands have received much attention in coordination and supramolecular chemistry [ $1-5]$. Owing to the versatile coordination geometry of silver, coordination numbers from two to six are possible [6-10], and because of the relatively weak nature of many Ag-ligand interactions, such complexes are particularly susceptible to the influence of weaker supramolecular forces. Thus, one can not precisely predict what structures will be finally formed for the silver(I) complexes, and more work needs to be carried out to understand the influence effects of such complexes, which has becoming an interesting topic in supramolecular chemistry. In recent years, the self-assembly and structures of a number of silver complexes have been studied. Most of the complexes show interesting luminescence property [11-13] and biological activities [14-17]. Compared to other applications, the cytotoxicity property of the silver complexes received particular attention [ 18-20]. 3-Aminopyrazine-2-carboxylic acid (HL) is a hopeful ligand containing carboxylic group, amine and pyrazine nitrogen atoms. Some nickel [21 ], cobalt [22 ], mercury [23 ], zinc [24 ], manganese [25] and lanthanide [26] complexes derived from HL have been reported. However, no silver complex has been reported so far. In the present work, a novel ladder-like polymeric silver(I) complex, $\left[\mathrm{Ag}_{2} \mathrm{~L}_{2}\right]_{n} \cdot 2 n \mathrm{H}_{2} \mathrm{O}$, is presented.

(C) Li G.-S., Zhang H.-L., 2015 


\section{EXPERIMENTAL}

Materials and measurements. 3-Aminopyrazine-2-carboxylic acid and silver oxide were purchased from Fluka and used as received. The solvents used were of reagent grade. Elemental analyses were carried out using a Perkin-Elmer $2400 \mathrm{II}$ elemental analyser. The infrared spectrum was recorded on a Perkin-Elmer FT-IR spectrophotometer with a $\mathrm{KBr}$ disc. Thermal analysis was performed with a Pyris 1 thermogravimetric analyser. The X-ray diffraction was carried out on a Bruker SMART 1000 CCD area diffractometer at 298(2) K.

Synthesis of the complex. 3-Aminopyrazine-2-carboxylic acid $(0.28 \mathrm{~g}, 2 \mathrm{mmol})$ and $\mathrm{Ag}_{2} \mathrm{O}(0.23 \mathrm{~g}$, $1 \mathrm{mmol}$ ) were mixed and stirred in a $30 \%$ aqueous ammonia $(30 \mathrm{~mL})$. The mixture was stirred at room temperature until all solid dissolved. The clear colorless solution was kept still at room temperature in dark for several days, to give well-shaped block-like single crystals. Yield: $38 \%$. Anal. Calcd. for $\mathrm{C}_{10} \mathrm{H}_{12} \mathrm{Ag}_{2} \mathrm{~N}_{6} \mathrm{O}_{6}(\%)$ : C 22.7, H 2.3, N 15.9. Found (\%): C 22.9, H 2.3, N 15.8. IR ( $\left.\mathrm{KBr}, \mathrm{cm}^{-1}\right)$ : $3407 \mathrm{~m}, 3265 \mathrm{w}, 1604 \mathrm{~s}, 1555 \mathrm{~m}, 1468 \mathrm{w}, 1430 \mathrm{w}, 1381 \mathrm{~m}, 1326 \mathrm{w}, 1232 \mathrm{w}, 1165 \mathrm{~m}, 910 \mathrm{w}, 823 \mathrm{w}, 557 \mathrm{w}$.

X-ray crystallography. A suitable single crystal of the complex was mounted on the top of a glass fiber. Graphite-monochromatized $\mathrm{Mo} K_{\alpha}$ radiation $(\lambda=0.71073 \mathrm{mmol})$ and the $\omega$ scan technique were used to collect the diffraction data. Absorption correction was applied with SADABS [27]. The structure of the complex was solved with direct method and refined with a full-matrix least-squares technique with SHELXTL [28]. Anisotropic thermal parameters were applied to all non-hydrogen atoms. The hydrogen atoms of the water molecules were located from electronic density maps, with $\mathrm{O} \cdots \mathrm{H}$ and $\mathrm{H} \cdots \mathrm{H}$ distances restrained to $0.85(1) \mathrm{mmol}$ and $1.37(2) \mathrm{mmol}$, respectively. The other hydrogen atoms were generated geometrically. The crystallographic data and the details of the data collection and refinement for the complex are listed in Table 1. Selected bond lengths and angles are given in Table 2. Hydrogen bonding information is given in Table 3. Crystallographic data for the complex has been deposited with the Cambridge Crystallographic Data Centre (CCDC 1008305).

Crystallographic data for the complex

\begin{tabular}{l|c}
\hline Empirical formula & $\mathrm{C}_{10} \mathrm{H}_{12} \mathrm{Ag}_{2} \mathrm{~N}_{6} \mathrm{O}_{6}$ \\
$F W$ & 528.0 \\
Crystal shape, colour & Block, colorless \\
Crystal size, mm & $0.18 \times 0.17 \times 0.12$ \\
Crystal system & Monoclinic \\
Space group & $P 2_{1} / c$ \\
$\lambda\left(\mathrm{Mo} K_{\alpha}\right), \AA$ & 0.71073 \\
$T, \mathrm{~K}$ & $298(2)$ \\
$\mu, \mathrm{mm}^{-1}$ (Mo $\left.K_{\alpha}\right)$ & 2.850 \\
Unit cell dimensions $a, b, c, \AA ; \beta$, deg. & $13.017(2), 7.1466(9), 15.064(2) ; 94.518(2)$ \\
$V, \AA^{3} ; Z$ & $1397.0(3) ; 4$ \\
$T_{\text {min }} / T_{\text {max }}$ & $0.6279 / 0.7260$ \\
No. of measured / unique reflections & $7709 / 2623$ \\
No. of observed reflections $[I \geq 2 \sigma(I)]$ & 2305 \\
Data / restraints / parameters & $2623 / 9 / 229$ \\
$R_{\text {int }}$ & 0.0336 \\
$F(000)$ & 1024 \\
Goodness of fit on $F^{2}$ & 1.305 \\
$R_{1}, w R_{2}[I \geq 2 \sigma(I)]$ & $0.0822,0.1761$ \\
$R_{1}, w R_{2}$ (all data) & $0.0908,0.1795$ \\
Largest and deepest diff. peak and hole, e/ $\AA^{3}$ & 1.349 and -1.272 \\
&
\end{tabular}


Selected bond lengths $(\AA)$ and angles (deg.) for the complex

\begin{tabular}{|c|c|c|c|c|c|c|c|}
\hline \multicolumn{4}{|c|}{ Bond lengths } & \multicolumn{4}{|c|}{ Bond angles } \\
\hline $\mathrm{Ag} 1-\mathrm{N} 1$ & $2.212(10)$ & $\mathrm{Ag} 1-\mathrm{O} 1$ & $2.500(10)$ & $\mathrm{N} 2-\mathrm{Ag} 1-\mathrm{N} 1 \mathrm{~A}$ & $171.0(4)$ & $\mathrm{N} 2-\mathrm{Ag} 1-\mathrm{O} 1 \mathrm{~A}$ & $107.2(3)$ \\
\hline $\mathrm{Ag} 1-\mathrm{N} 2 \mathrm{~A}$ & $2.183(10)$ & $\mathrm{Ag} 2-\mathrm{N} 5 \mathrm{~A}$ & $2.202(10)$ & $\mathrm{N} 1-\mathrm{Ag} 1-\mathrm{O} 1$ & $70.2(3)$ & $\mathrm{N} 5-\mathrm{Ag} 2-\mathrm{N} 4 \mathrm{~A}$ & $169.1(4)$ \\
\hline Ag2-N4 & $2.241(9)$ & $\mathrm{Ag} 2-\mathrm{O} 3$ & $2.573(10)$ & $\mathrm{N} 5-\mathrm{Ag} 2-\mathrm{O} 3 \mathrm{~A}$ & $105.7(3)$ & $\mathrm{N} 4-\mathrm{Ag} 2-\mathrm{O} 3$ & $69.7(3)$ \\
\hline
\end{tabular}

Symmetry code for A: $x, 1+y, z$.

Cytotoxicity assay. Human lung carci$\mathrm{T}$ a b l e 3 noma A549 cells were cultured in an F12 K medium supplemented with $10 \%$ heat inactivated fetal bovine serum (FBS), 2 mM glutamine, $100 \mathrm{U} / \mathrm{mL}$ penicillin, and $100 \mu \mathrm{g} / \mathrm{mL}$ streptomycin, and maintained at $37{ }^{\circ} \mathrm{C}$ in humidified atmosphere of $5 \% \mathrm{CO}_{2}$. MTT assay was conducted and modified as described in the literature [29]. A549 cells $\left(2.5 \times 10^{3}\right.$ cells $)$ were seeded on $96-$ well microtitre plates in $\mathrm{F} 12 \mathrm{~K}$ medium with $10 \%$ FBS and incubated overnight. The cell culture medium was replaced by the different dose of compounds solution, and then the cells were cultured for another $72 \mathrm{~h}$. The MTT [3-(4,5-dimethylthiazol-2-yl)-2,5-diphenyltetrazolium bromide] reagent was added to the cell supernatant for a final concentration of $0.5 \mathrm{mg} / \mathrm{mL}$ of $\mathrm{MTT}$. After $3 \mathrm{~h}$ the cell culture medium was removed. Formazan crystals in adherent cells were dissolved in $200 \mu \mathrm{L}$ DMSO and the absorbance of the formazan solution was measured. Each compound was tested in triplicate and the experiments were repeated three times.

\section{RESULTS AND DISCUSSION}

Synthesis. The synthetic procedure of the complex is described as follows:<smiles>Nc1nccnc1C(=O)O</smiles>

In the present complex, the $\mathrm{Ag}$ atom combines with the pyrazine $\mathrm{N}$ and carboxylate $\mathrm{O}$ atoms, instead of the amino $\mathrm{N}$ atom. This is due to the strain of the five-membered chelate ring is weaker than the four-membered chelate ring. Elemental analyses of the complex are in good agreement with the expected values. Even though most silver complexes are sensitive to light, this complex is very stable.

Infrared spectrum of the complex. The medium and broad absorption centered at $3407 \mathrm{~cm}^{-1}$ can be assigned to the vibration of the water molecules. The weak and sharp absorption at $3265 \mathrm{~cm}^{-1}$ comes from the $\mathrm{N}-\mathrm{H}$ vibrations of the amino groups. The $v_{\mathrm{as}}(\mathrm{COO})$ is related to the strong band observed at $1604 \mathrm{~cm}^{-1}$, whereas the $v_{\mathrm{s}}(\mathrm{COO})$ is attributed to the medium band observed at $1381 \mathrm{~cm}^{-1}$. This gives rise to a $\Delta v$ of $223 \mathrm{~cm}^{-1}$ characteristic of the monodentate coordination of the carboxylate group [ 30 ]. 


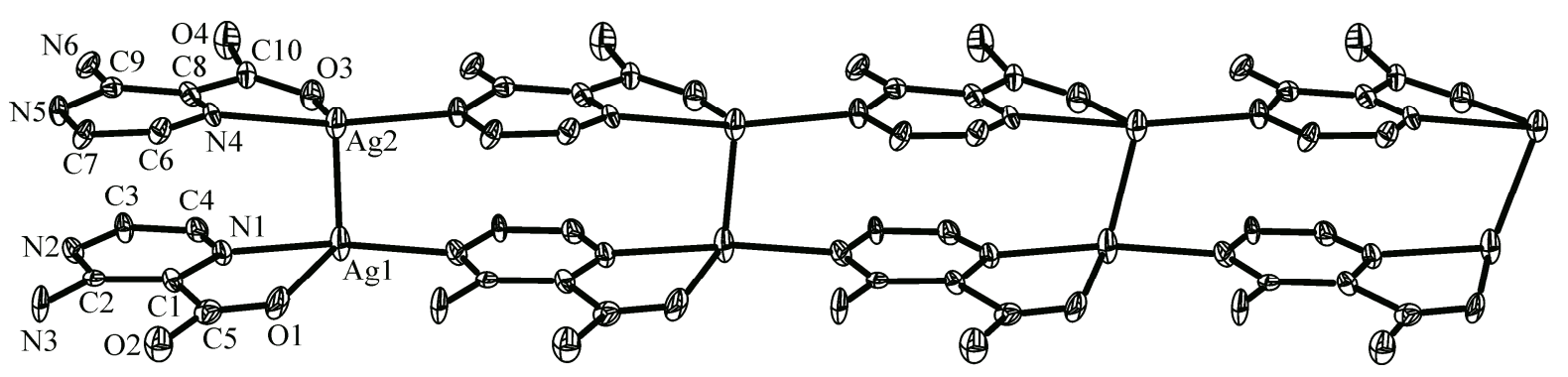

Fig. 1. Molecular structure of the silver complex with $30 \%$ probability level

Structure description of the complex. The molecular structure of the complex is shown in Fig. 1. The smallest repeat unit contains a $\left[\mathrm{Ag}_{2} \mathrm{~L}_{2}\right]$ moiety and two water molecules. The $\mathrm{Ag} \cdots \mathrm{Ag}$ distance is 3.176(1) mmol. Each Ag atom is in a $Y$-shaped coordination, with one carboxylate $\mathrm{O}$ and two pyrazine $\mathrm{N}$ atoms from two ligands. The $\mathrm{Ag} 1$ and $\mathrm{Ag} 2$ atoms deviate from the least-squares planes defined by the corresponding three donor atoms by 0.168(2) mmol and 0.198(2) mmol, respectively. The distortion of the coordination can be observed from the bond lengths and angles related to the $\mathrm{Ag}$ atom. The $\mathrm{Ag}-\mathrm{O}$ bonds are much longer than the $\mathrm{Ag}-\mathrm{N}$ bonds. Due to the strain created by the fivemembered chelated rings $\mathrm{Ag} 1-\mathrm{N} 1-\mathrm{C} 1-\mathrm{C} 5-\mathrm{O} 1$ and $\mathrm{Ag} 2-\mathrm{N} 4-\mathrm{C} 8-\mathrm{C} 10-\mathrm{O} 3$, the angles $\mathrm{N} 1-\mathrm{Ag} 1-\mathrm{O} 1$ and $\mathrm{N} 4-\mathrm{Ag} 2-\mathrm{O} 3$ are much smaller. Yet, both $\mathrm{Ag}-\mathrm{O}$ and $\mathrm{Ag}-\mathrm{N}$ bonds are comparable to those observed in similar silver complexes [31,32]. The dihedral angle between the leastsquares planes of $\mathrm{N} 1-\mathrm{C} 1-\mathrm{C} 2-\mathrm{N} 2-\mathrm{C} 3-\mathrm{C} 4$ and $\mathrm{O} 1-\mathrm{C} 5-\mathrm{O} 2$ is $6.4(3)^{\circ}$, and that between the least-squares planes of $\mathrm{N} 4-\mathrm{C} 6-\mathrm{C} 7-\mathrm{N} 5-\mathrm{C} 9-\mathrm{C} 8$ and $\mathrm{O} 3-\mathrm{C} 10-\mathrm{O} 4$ is $17.4(3)^{\circ}$. The dinuclear silver moieties are linked through 3-aminopyrazine-2-carboxylate ligands, to form 1D ladder-like chain along the $b$ axis (Fig. 2). The water molecules are linked to the silver chain through intermolecular $\mathrm{N}-\mathrm{H} \cdots \mathrm{O}$ and $\mathrm{O}-\mathrm{H} \cdots \mathrm{O}$ hydrogen bonds (Table 3 ). There are $\pi \cdots \pi$ interactions between the chains (Table 4).

Thermal analysis. Fig. 3 shows the TG-DT curves of the complex. The complex undergoes three steps of decomposition. The first step, starting from $80^{\circ} \mathrm{C}$ to $140{ }^{\circ} \mathrm{C}$, corresponds to the loss of water molecules. The weight loss of $7.3 \%$ is close to the calculated value of $6.9 \%$. The second step, starting

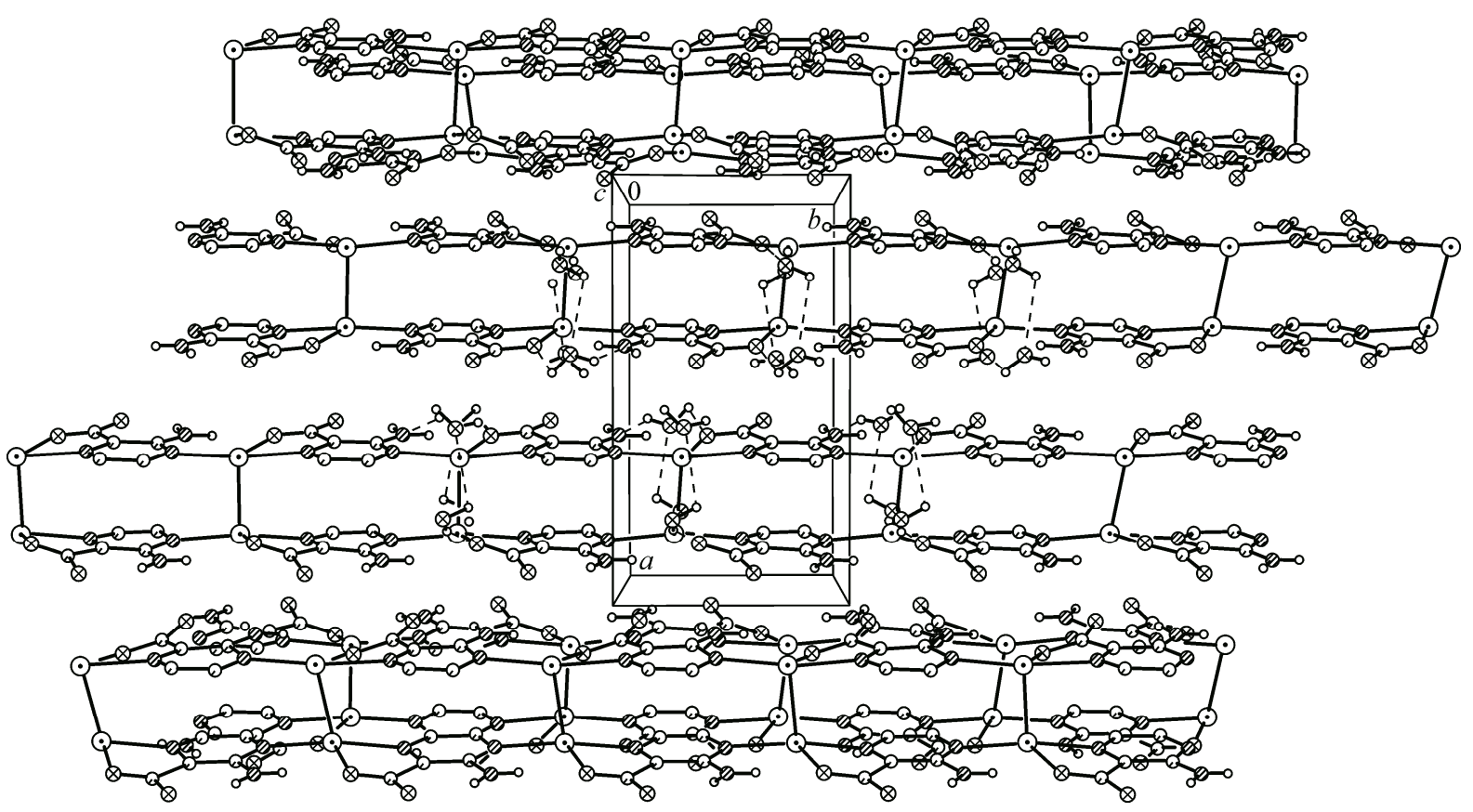

Fig. 2. Molecular packing of the complex, viewed along the $c$ axis. Hydrogen bonds are shown as dashed lines 
Parameters between the planes for the complex

\begin{tabular}{c|c|c|c|c|c}
\hline $\mathrm{Cg}$ & $\begin{array}{c}\text { Distance between } \\
\text { ring centroids, } \AA\end{array}$ & $\begin{array}{c}\text { Dihedral } \\
\text { angle, deg. }\end{array}$ & $\begin{array}{c}\text { Perpendicular distance } \\
\text { of } \mathrm{Cg}(I) \text { on } \mathrm{Cg}(J), \AA\end{array}$ & $\begin{array}{c}\text { Perpendicular distance } \\
\text { of } \operatorname{Cg}(I) \text { on } \mathrm{Cg}(J), \AA\end{array}$ & Slippage \\
\hline $\mathrm{Cg}(1)-\mathrm{Cg}(1)^{\mathrm{iii}}$ & 3.410 & 0 & 3.274 & 3.274 & 0.954 \\
$\mathrm{Cg}(1)-\mathrm{Cg}(2)^{\mathrm{iii}}$ & 4.340 & 5 & 3.244 & 3.339 & \\
$\mathrm{Cg}(1)-\mathrm{Cg}(3)$ & 3.674 & 6 & 3.215 & -3.344 & \\
$\mathrm{Cg}(2)-\mathrm{Cg}(3)$ & 3.462 & 2 & 3.243 & -3.276 & \\
$\mathrm{Cg}(3)-\mathrm{Cg}(3)^{\mathrm{iv}}$ & 4.895 & 0 & -3.047 & -3.047 & 3.831 \\
$\mathrm{Cg}(3)-\mathrm{Cg}(3)^{\mathrm{v}}$ & 4.726 & 0 & -3.162 & -3.162 & 3.512
\end{tabular}

Symmetry codes: ${ }^{\text {iii }} 1-x, 1-y, 1-z ;{ }^{\text {iv }}-x,-y, 1-z ;{ }^{\mathrm{v}}-x, 1-y, 1-z$.

$\mathrm{Cg}(1), \mathrm{Cg}(2)$, and $\mathrm{Cg}(3)$ are the centroids of $\mathrm{Ag} 1-\mathrm{O} 1-\mathrm{C} 5-\mathrm{C} 1-\mathrm{N} 1, \mathrm{~N} 1-\mathrm{C} 1-\mathrm{C} 2-\mathrm{N} 2-\mathrm{C} 3-$ $\mathrm{C} 4$, and $\mathrm{N} 4-\mathrm{C} 6-\mathrm{C} 7-\mathrm{N} 5-\mathrm{C} 9-\mathrm{C} 8$, respectively.

from $250{ }^{\circ} \mathrm{C}$ to $380{ }^{\circ} \mathrm{C}$, corresponds to the loss of the ligands, and the formation of $\mathrm{Ag}_{2} \mathrm{O}$. The weight loss of $51 \%$ agrees well with the calculated value of $49 \%$. Then, $\mathrm{Ag}_{2} \mathrm{O}$ decompose to give $\mathrm{Ag}$ as the final product.

Cytotoxic property. A549 cells were used by MTT method to study the growth inhibitory effects of the complex on lung cancer cells. The $\mathrm{IC}_{50}$ value for the complex is $10.3 \pm 1.5 \mu \mathrm{M}$. As a comparison, the silver nitrate and cisplatin showed $\mathrm{IC}_{50}$ values of $8.7 \pm 0.9 \mu \mathrm{M}$ and $6.9 \pm 1.1 \mu \mathrm{M}$, and the ligand itself showed no activity. Thus, the cytotoxic property of the complex is weaker than the silver nitrate and cisplatin. However, considering the obvious side effects of the silver

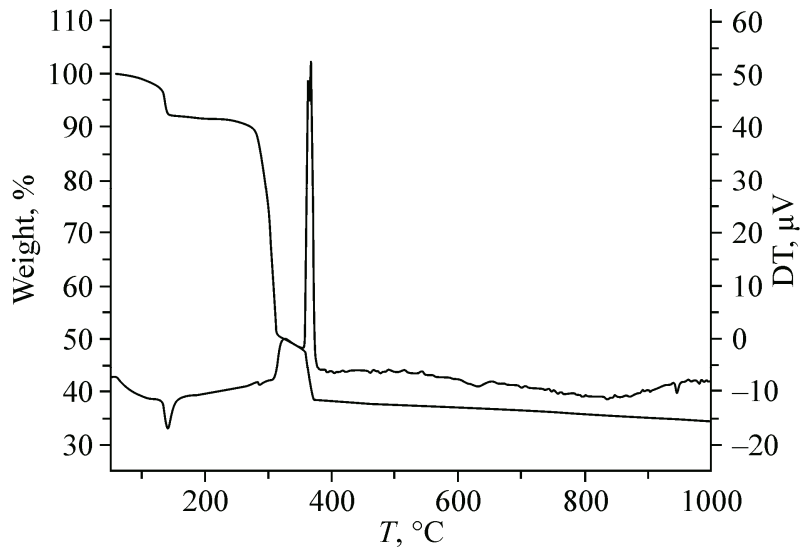

Fig. 3. TG curve of the complex nitrate and cisplatin, the present silver complex is also a promising drug, and deserves further study.

\section{REFERENCES}

1. Han S.H., Lee S.W. // Polyhedron. - 2012. - 31, N 1. - P. $255-264$.

2. Park K.-M., Lee E., Park C.S., Lee S.S. // Inorg. Chem. - 2011. - 50, N 23. - P. 12085 - 12090.

3. Awaleh M.O., Badia A., Brisse F. // Cryst. Growth Des. - 2006. - 6, N 12. - P. $2674-2685$.

4. Whitcomb D.R., Rajeswaran M. // Polyhedron. - 2006. - 25, N 8. - P. $1747-1752$.

5. Zhang L., You Z.-L., Jiao Q.-Z. // Trans. Met. Chem. - 2008. - 33, N 5. - P. $573-577$.

6. You Z.-L., Zhang L., Shi D.-H., Ni L.-L. // Inorg. Chem. Commun. - 2009. - 12, N 12. - P. 1231 - 1233.

7. Whitcomb D.R., Rajeswaran M. // Inorg. Chim. Acta. - 2008. - 361, N 5. - P. $1357-1362$.

8. Curran R., Lenehan J., McCann M., Kavanagh K., Devereux M., Egan D.A., Clifford G., Keane K., Creaven B.S., McKee V. // Inorg. Chem. Commun. - 2007. - 10, N 10. - P. $1149-1153$.

9. Wang D.-F., Wang Z.-H., Lu B.-W., Chen S.-F., Zhang T., Huang R.-B., Zheng L.-S. // J. Mol. Struct. - 2014. - 1059, N 1. - P. $81-86$.

10. Marandi F., Hosseini N., Krautscheid H., Lassig D., Lincke J., Rafiee M., Asl Y.A. // J. Mol. Struct. - 2011. - 1006, N 1-3. - P. $324-329$.

11. Liu X., Li L., Yang Y.-Z., Huang K.-L.// Dalton Trans. - 2014. - 43, N 10. - P. 4086 - 4092.

12. Huang X., Li Z.-F., Jin Q.-H., Qiu Q.-M., Cui Y.-Z., Yang Q.-R. // Polyhedron. - 2013. - 65. - P. 129 - 135.

13. Kaur G., Verma R.K., Rai D.K., Rai S.B. // J. Lumin. - 2012. - 132, N 7. - P. 1683 - 1687.

14. Hackenberg F., Lally G., Muller-Bunz H., Paradisi F., Quaglia D., Streciwilk W., Tacke M. // Inorg. Chim. Acta. - 2013. - 395. - P. $135-144$. 
15. Liu W.K., Bensdorf K., Hagenbach A., Abram U., Niu B., Mariappan A., Gust R. // Eur. J. Med. Chem. - 2011. - 46, N 12. - P. 5927 - 5934.

16. Zartilas S., Hadjikakou S.K., Hadjiliadis N., Kourkoumelis N., Kyros L., Kubicki M., Baril M., Butler I.S., Karkabounas S., Balzarini J. // Inorg. Chim. Acta - 2009. - 362, N 3. - P. 1003 - 1010.

17. Rowan R., Tallon T., Sheahan A.M., Curran R., McCann M., Kavanagh K., Devereux M., McKee V. // Polyhedron. - 2006. - 25, N 8. - P. $1771-1778$.

18. Tan X.-J., Liu H.-Z., Ye C.-Z., Lou J.-F., Liu Y., Xing D.-X., Li S.-P., Liu S.-L., Song L.-Z. // Polyhedron. - 2014. - 71. - P. $119-132$.

19. Li Y.-L., Qin Q.-P., An Y.-F., Liu Y.-C., Huang G.-B., Luo X.-J., Zhang G.-H. // Inorg. Chem. Commun. $-2014 .-40$, N 1. - P. $73-77$.

20. Gandin V., Pellei M., Marinelli M., Marzano C., Dolmella A., Giorgetti M., Santini C. // J. Inorg. Biochem. - 2013. - 129. - P. $135-144$.

21. Ptasiewicz-Bak H., Leciejewicz J. // Pol. J. Chem. - 1999. - 73, N 4. - P. 717 - 725.

22. Bouchene R., Bouacida S., Berrah F., Belhouas R., Merazig H. // Acta Crystallogr. - 2013. - E69, N 2. - P. m129-m130.

23. Dehghanpour S., Jahani K., Mahmoudi A., Babakhodaverdi M., Notash B. // Inorg. Chem. Commun. - 2012. - 25, N 1. - P. $79-82$.

24. Gao S., Ng S.W. // Acta Crystallogr. - 2010. - E66, N 10. - P. m1466- m1467.

25. Gao S., Ng S.W. // Acta Crystallogr. - 2010. - E66, N 9. - P. m1223.

26. Deng Z.-P., Kang W., Huo L.-H., Zhao H., Gao S. // Dalton Trans. - 2010. - 39, N 27. - P. $6276-6284$.

27. Sheldrick G.M. SADABS. Program for Empirical Absorption Correction of Area Detector. - Germany: University of Göttingen, 1996.

28. Sheldrick G.M. SHELXTL, Version 6.10, Software Reference Manual. - Madison, Wisconsin, USA: Bruker Instrumentation, 2000.

29. Zhao Y., Liu W., Zhou Y., Zhang X., Murphy P.V. // Bioorg. Med. Chem. Lett. - 2010. - 20, N 24. - P. 7540 7543.

30. Nakamoto K. Infrared and Raman Spectra of Inorganic and Coordination Compounds. - New York: Wiley, 1986.

31. Wang N., Li B. // J. Chem. Crystallogr. - 2011. - 41, N 2. - P. 219 - 222.

32. Sun D., Wei Z.-H., Yang C.-F., Wang D.-F., Zhang N., Huang R.-B., Zhang L.-S. // CrystEngComm. - 2011. -13, N 5. - P. $1591-1601$. 